\title{
MODELING AND SIMULATION OF GAS DEHYDRATION USING CUBIC PLUS ASSOCIATION EQUATION OF STATE MODEL
}

\author{
S.Hasan, Asma.A.Mohamed, Marwa Mostafa, M.Gamal \\ Chemical Engineering Department, Minya University, Egypt \\ E-mail:samar.hasan.2210@gmail.com
}

\begin{abstract}
Dehydration process is an important focal unit in offshore gas processing to avoid industrial problems accompanied by hydrated gas processing and pipeline transport system such as corrosion and hydrates formation. The gas dehydration process has been entirely simulated and optimized in Aspen HYSYS V8.8 using cubic plus association equation of state thermodynamic package and compared to the simulation results obtained by using glycol package which is developed particularly for gas dehydration modeling.
\end{abstract}

Keywords: Dehydration process optimization; gas dehydration process simulation; natural gas thermodynamics.

\section{INTRODUCTION}

At the wellhead, reservoir fluids generally are saturated with water. The water in the gas can present some problems for example, formation of solid hydrates can plug valves, fittings or pipes, the presence of water along with $\mathrm{H}_{2} \mathrm{~S}$ or $\mathrm{CO}_{2}$ can cause corrosion problems and water can condense in the pipeline causing erosion or corrosion. Generally, a dehydration unit is used in gas plants to meet a pipeline specification. There are several different processes available for dehydration: glycols, silica gel, or molecular sieves. The natural gas industry commonly uses tri-ethylene glycol (TEG) for gas dehydration where low gas dew point temperatures are required. Likewise in the design of offshore platforms in the Arctic or North Sea regions or for other cryogenic processes [1]. Natural gas is processed and transported by gas pipeline system that should meet certain predefined specifications for instance, $\mathrm{H}_{2} \mathrm{~S}$ content and dew point at which water vapor condenses from the gas stream. Glycol process is considered the optimal and most commonly applied process in the field of gas industry. Moreover, glycol has high tendency toward water rather than has various types for example, MEG, DEG, TEG, that's of interest and applied in the present study. Simulation of gas dehydration thermodynamics is uneasy owing to of the non-ideal behavior between water and glycol mixture due to mutual interaction between each other's which cannot be described precisely using Peng-Robinson thermodynamic equation of state that is still applicable because of its internal fit of binary interaction parameters (BIP) to accurately predict natural gas dehydration absorbers and TEG solutions regeneration, however was giving strange behavior outside normal gas dehydration operating conditions $[2, \underline{3}]$.

\section{PROCESS DESCRIPTION}

Gas Dehydration process is consisting of several operation units for instance, contactor tower, regenerator column and heat exchanger. Fig. (1) shows typical gas dehydration process. During the process, lean glycol enters the absorption tower at the top side whereas rich solvent is collected at the bottom of the column and will send to the regenerator. Wet gas enters to the absorption column after passed through inlet scrubber that is not taken into account in this 
simulation study since the composition of natural gas stream is supplied on a wet basis without free water entrained. The scrubber removes free liquid and liquid droplets in the gas, removing liquid in the scrubber diminish the amount of water that has to remove in the absorption column, and this also decrease the size of the column and thus lowering the TEG needed in process. Heat exchanger utilized for cooling of wet gas before enters to scrubber. Rich TEG passes through a coil for heat exchange with lean TEG stream, which is used as reflux at the top of the regenerator tower; to increase its temperature. A flash tank is utilized for the removal of absorbed acidic gases and hydrocarbons in TEG before rich solvent enter to the regenerator, which is a distillation column, and separate the TEG and water content. Indeed, rich TEG is preheated in another heat exchanger before it fed to the regeneration section. At the end of the process cycle, the regenerated TEG will cool in the third step of heat exchanger by dry gas stream as a cold fluid and will back to the dehydration absorber for reuse, making the process well heat integrated [4].

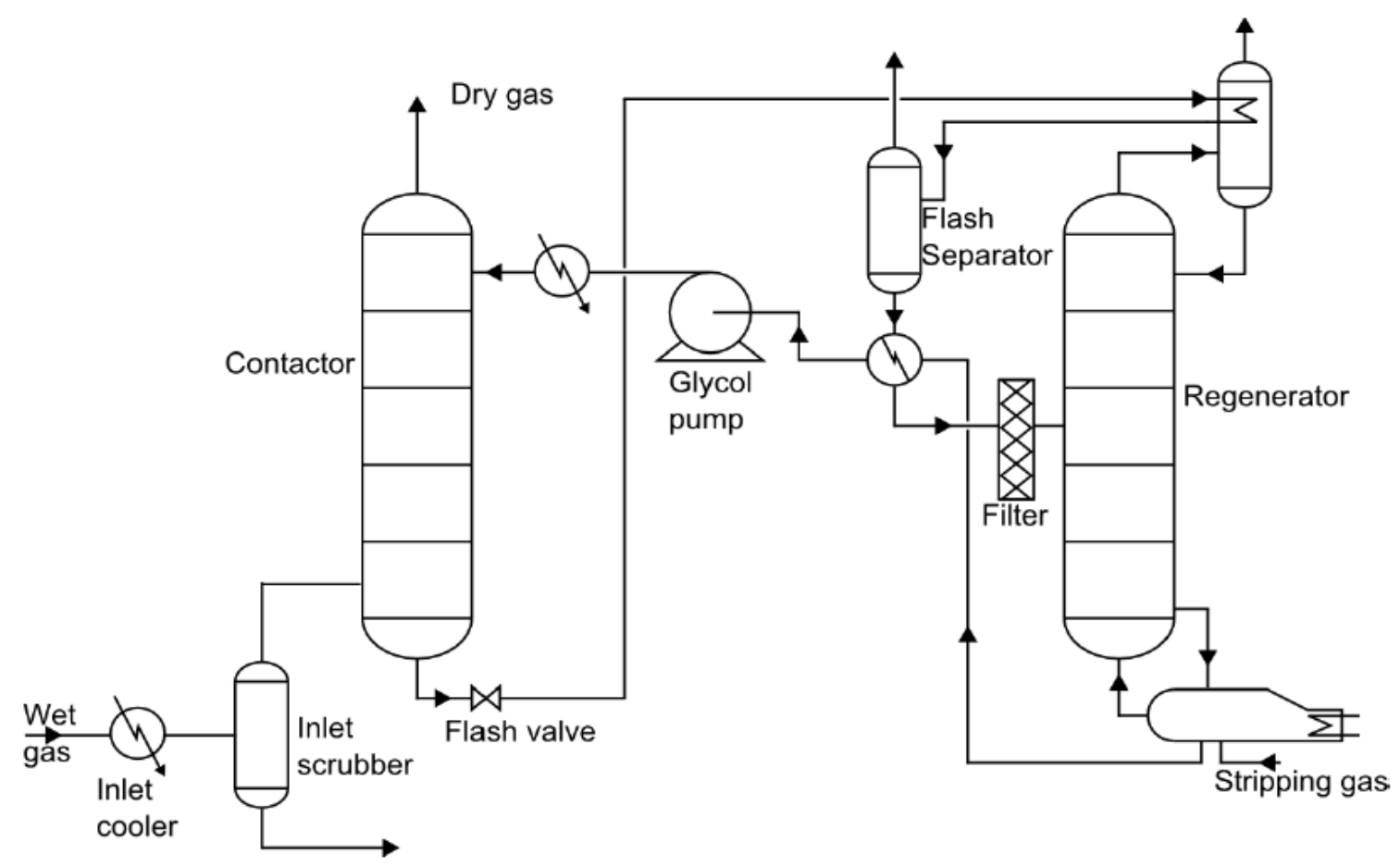

Fig.1. Schematic process flow diagram for glycol gas dehydration plant

\section{PROCESS THERMODYNAMICS}

An actual plant in Egypt has wet feed gas with composition and conditions as shown in Table (1), [5]. In process simulation thermodynamics are used to calculate the relationship between energy consumption/release, pressure, temperature, volume and phase equilibrium [2].

A fluid package is a combination of a component list and a collection of task or industry-specific property-derivation methods called a property package. Selection of the appropriate property package is one of the most important considerations for a successful process simulation [5] . 
Table1. Dehydration plant feed gas composition and conditions

\begin{tabular}{|l|c|}
\hline Stream & Wet Gas Feed \\
\hline Temperature & $30{ }^{\circ} \mathrm{C}$ \\
\hline Pressure & 900 psia \\
\hline Flow Rate & 21 MMSCFD \\
\hline Composition & Mass Fraction \\
\hline Nitrogen & 0.0012 \\
\hline $\mathrm{H}_{2} \mathrm{O}$ & 0.0005 \\
\hline $\mathrm{CO}_{2}$ & 0.0019 \\
\hline $\mathrm{H}_{2} \mathrm{~S}$ & 0.0280 \\
\hline Methane & 0.3985 \\
\hline Ethane & 0.1992 \\
\hline Propane & 0.1793 \\
\hline i-Butane & 0.0496 \\
\hline n-Butane & 0.0806 \\
\hline i-Pentane & 0.0803 \\
\hline n-Pentane & 0.0049 \\
\hline n-Hexane & 0.0037 \\
\hline
\end{tabular}

The process simulation results are calculated according to the thermodynamic models selected in the Aspen HYSYS properties environment [6]. Often times, simulation results do not reflect what is really taking place in a process plant or field operation owing to improperly selected thermodynamic models, inadequate model parameters, incorrect hypothetical components generation and problems with plant data consistency [3]]. Aspen HYSYS simulation software provides numerous different thermodynamic models in the properties environment. Moreover the Aspen Properties models available through integration. Choosing a suitable property package is a key to produce accurate simulations [6]. In this study, we will discuss the preference between two different thermodynamic models CPA and glycol packages Fig. (2). Aspen HYSYS historically employed glycol property package for TEG. By utilization of the addition of Cubic-Plus-Association, or CPA, package in V8.8 or higher which allow to model dehydration with TEG, MEG and DEG. Glycol property package contains the TST (Twu-Sim-Tassone) equation of state to determine the phase behaviour more accurately and consistently for the TEG water mixture Eqs. (1-5). The CPA package Eq. (6) is an equation of state model based on the Soave-Redlich-Kwong (SRK) equation of state as a base and it also utilizes an association term similar to the statistical Association Fluid theory (SAFT) models. If the compounds used in the simulation do not have hydrogen bonding forces, the CPA package will reduce to the basic (SRK) model [6]. The following equations are the TST (Twu-Sim-Tassone) zero pressure mixing rules used for phase equilibrium prediction in the Glycol property package:

$$
\begin{gathered}
P=\frac{R T}{v-b}-\frac{a}{(v+3 b)(v-0.5 b)} \\
b=\sum_{i} \sum_{j} x_{i} x_{j}\left[\frac{1}{2}\left(b_{i}+b_{j}\right)\right]
\end{gathered}
$$

$$
a^{*}=b^{*}\left[\frac{a_{v d w}{ }^{*}}{b_{v d w}{ }^{*}}+\frac{1}{C_{r}}\left(\frac{A_{0}^{E}}{R T}-\frac{A_{0 v d w}^{E}}{R T}-\ln \left(\frac{b_{v d w}}{b}\right)\right)\right]
$$$$
\frac{A_{0 v d w}^{E}}{R T}=\frac{A_{\propto 0 v d w}^{E}}{R T}=C_{1}\left(\frac{a_{v d w}{ }^{*}}{b_{v d w}{ }^{*}}-\sum_{i} x_{i} \frac{a_{i}{ }^{*}}{b_{i}{ }^{*}}\right)
$$

$$
\frac{G^{E}}{R T}=\sum_{i}^{n} x_{i} \frac{\sum_{j}^{n} x_{j} \tau_{j i} G_{j i}}{\sum_{k}^{n} x_{k} G_{k i}}
$$

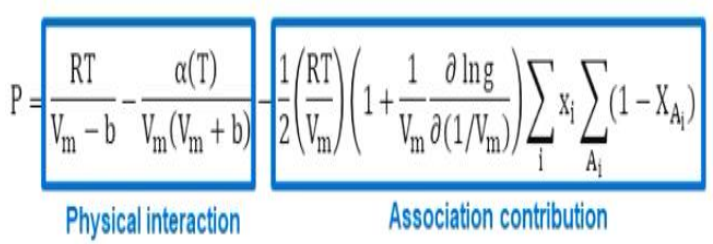


This model is applicable to cover vaporliquid and vapor-liquid-liquid equilibrium for mixtures with hydrocarbons, nonhydrocarbons like carbon dioxide, hydrogen sulfide and nitrogen, and polar or associating chemicals such as, water, alcohols, glycols, esters, and organic acids [6]. Therefore this promote the ability to model complex systems involving typical dehydration components makes CPA the ideal package for modeling natural gas dehydration. Thus CPA imparts more precise predictions of associating component equilibria compared to the glycol package. Experimental data from Herskowitz and Tsuji [7] used to validate CPA results so as to find out any deviation points. Fig. (2) and Fig. (3) illustrates the behavior of CPA calculation results against the data.
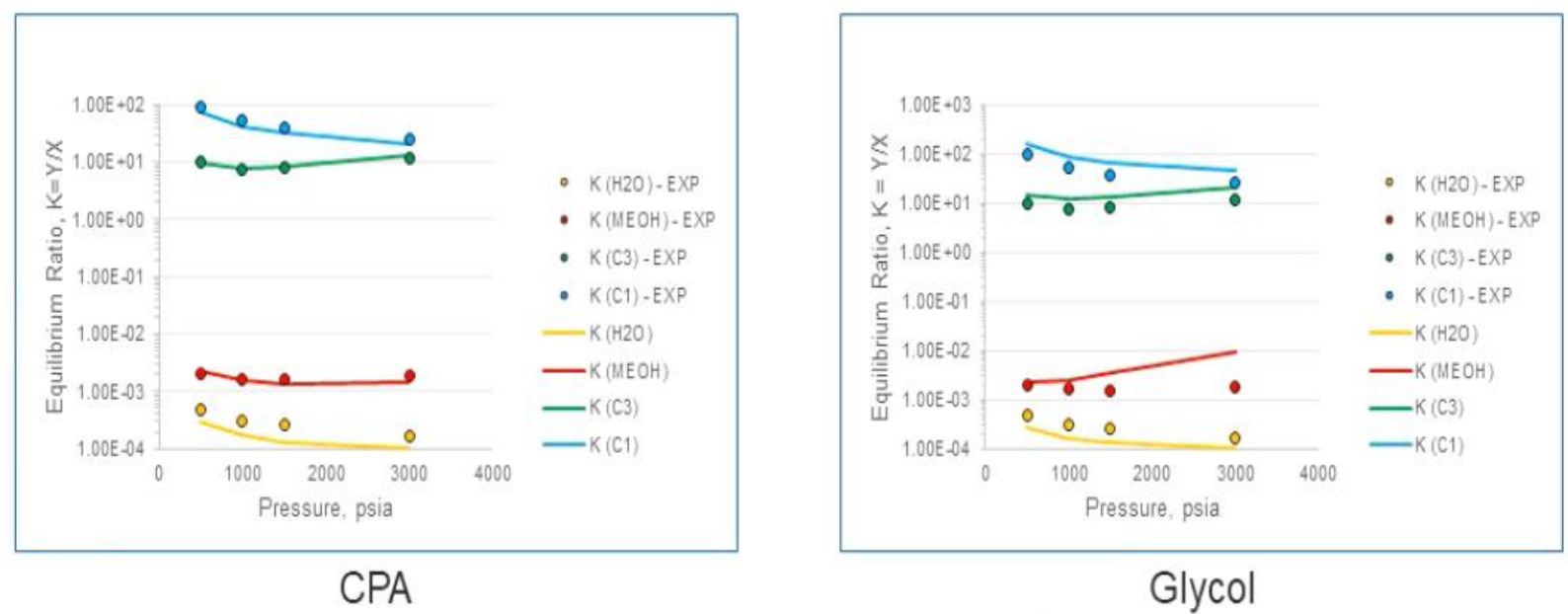

Fig.2. CPA provides more accurate modeling of associating components in comparison with the

Glycol package with respect to equilibrium data

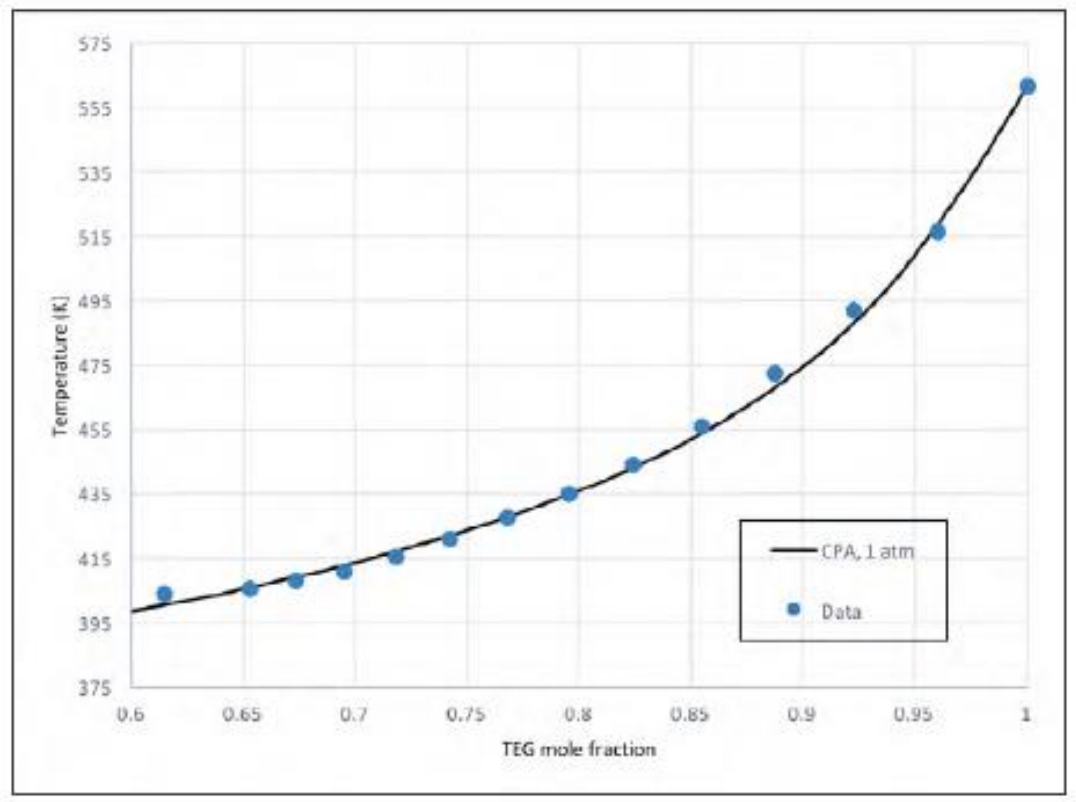

Fig.3. T-x diagram in the high TEG concentration region relevant to the TEG regenerator using the

Calculated values from CPA property package 


\section{PROCESS SIMULATION}

Aspen HYSYS starting from V8.8 was utilized in this work to simulate natural gas dehydration process to match plant data and to optimize process conditions. In earlier versions of Aspen HYSYS, the Glycol property package is the recommended thermodynamic model for simulation of TEG dehydration process. However, some deficiencies have been reported, such as when methanol is present. The Glycol property package is also limited to TEG only; EG and DEG are not supported [8].

In order to mimic saturated gas stream with water in the software there are two methods, first one is to do it manually, a stream of $100 \%$ water with a flow rate of approximately $1 \%$ of the inlet gas stream flow rate is added, mixing the gas and water streams using a mixer then the two phase mixture fed to a separator. Making use of an adjust operation to manipulate the flow rate of inlet water until the liquid flow from the separator is a small non-zero value. The second method is to use the saturate unit operation. After adding this unit operation, users can attach streams for inlet gas, outlet saturate gas and a pure water stream in order to make it work. In this case, it will not have the option to choose the amount of water added to the stream, HYSYS will simply saturate it [6]. Basically both techniques are implemented for confirmation of results.

The distillation column used for modeling the regenerator which is subjected to recover glycol solvent. The various glycol solvents are typical expensive making regeneration quite desirable. In this work the default conventional column specifications have been changed to enhance convergence. The key tower temperature is the reboiler temperature; therefore higher temperature will increase glycol purity, but also increase glycol degradation. The reboiler is operated around the decomposition temperature of the glycol, ensuring that as much water as possible is removed from glycol. From top column, typical temperatures in the column range from around $100^{\circ} \mathrm{C}$ at the condenser to about $200^{\circ} \mathrm{C}$ at the reboiler Fig. (4). Typical operating ranges for the contactor, flash and regenerator in the dehydration system using TEG Fig. (5).

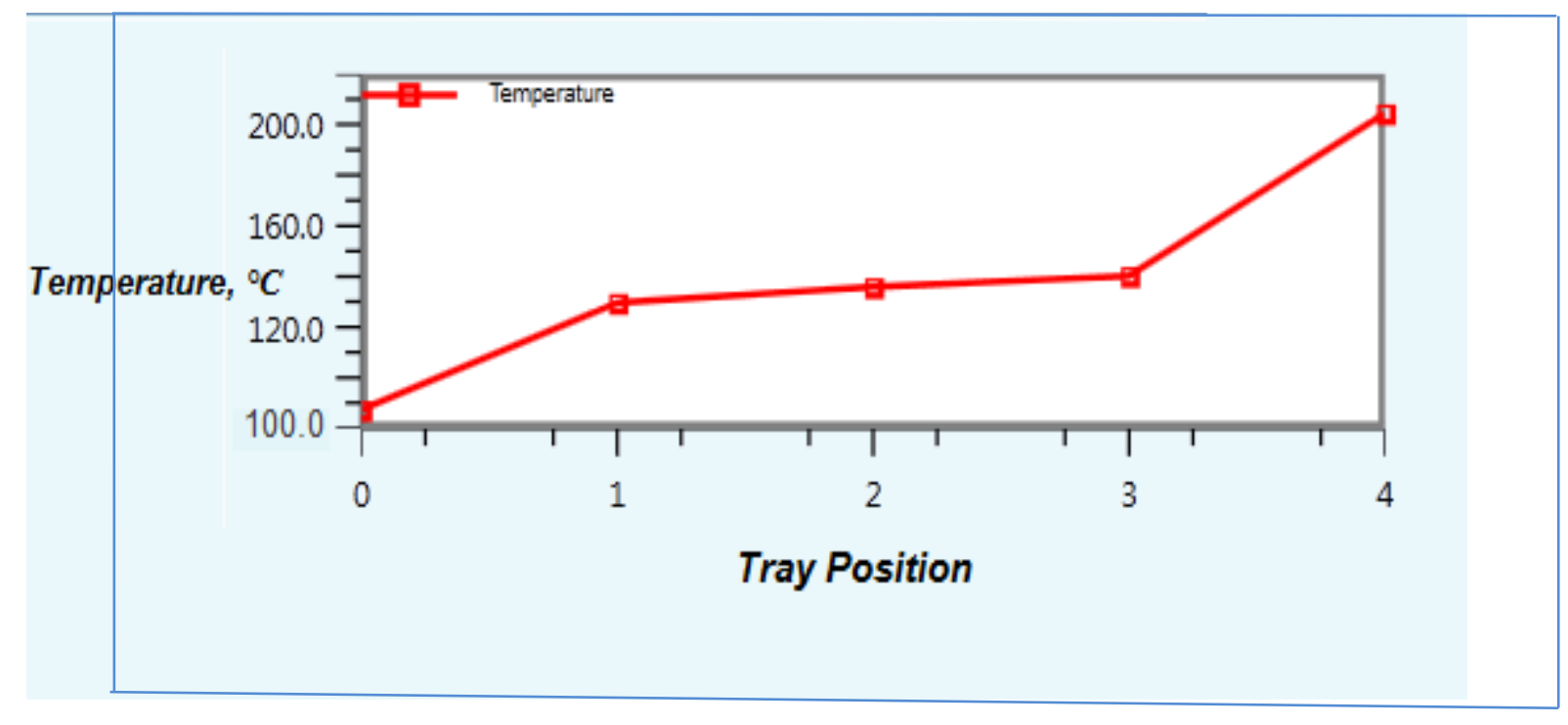

Fig.4. Temperature profile throughout regenerator tower plates 


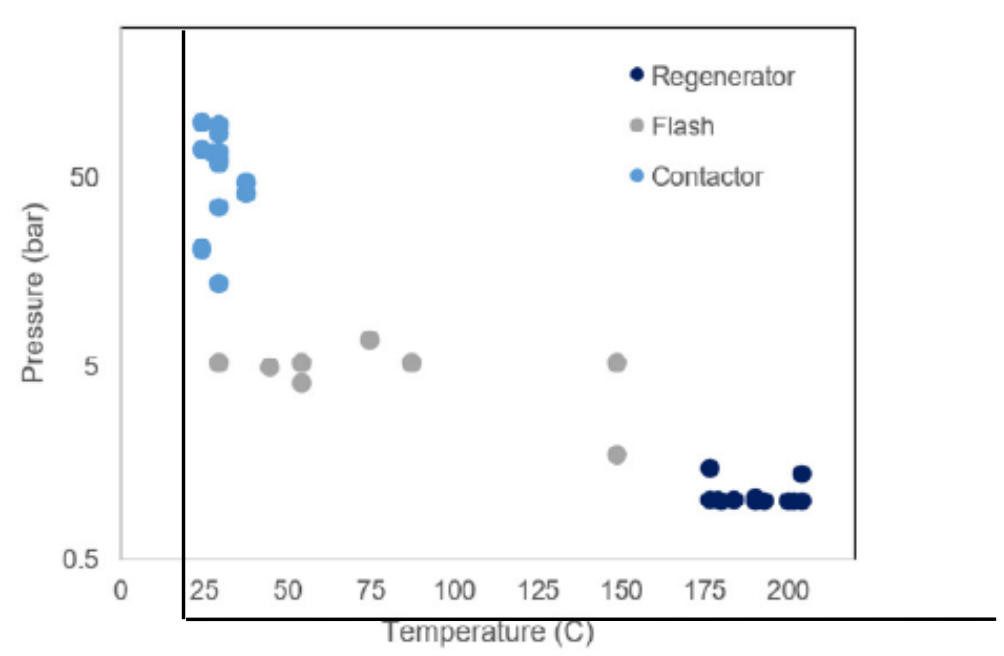

Fig.5. Operating conditions for TEG glycol dehydration process

A component splitter and some analysis tools in Aspen HYSYS software are utilized in the dehydration simulation flow sheet Fig. (6), to evaluate dew point temperature and amount of water in the final stream. Any glycol in the product dry gas stream will affect dew point calculations []․ Presence of glycol, amines, methanol or other polar compound that have strong affinity with water will affect the phase equilibrium modifying the liquid formation temperature, so component splitter is specified for this separation task. In industrial practice the product gas is demisted to remove these compounds and achieve much more accurate measurement.

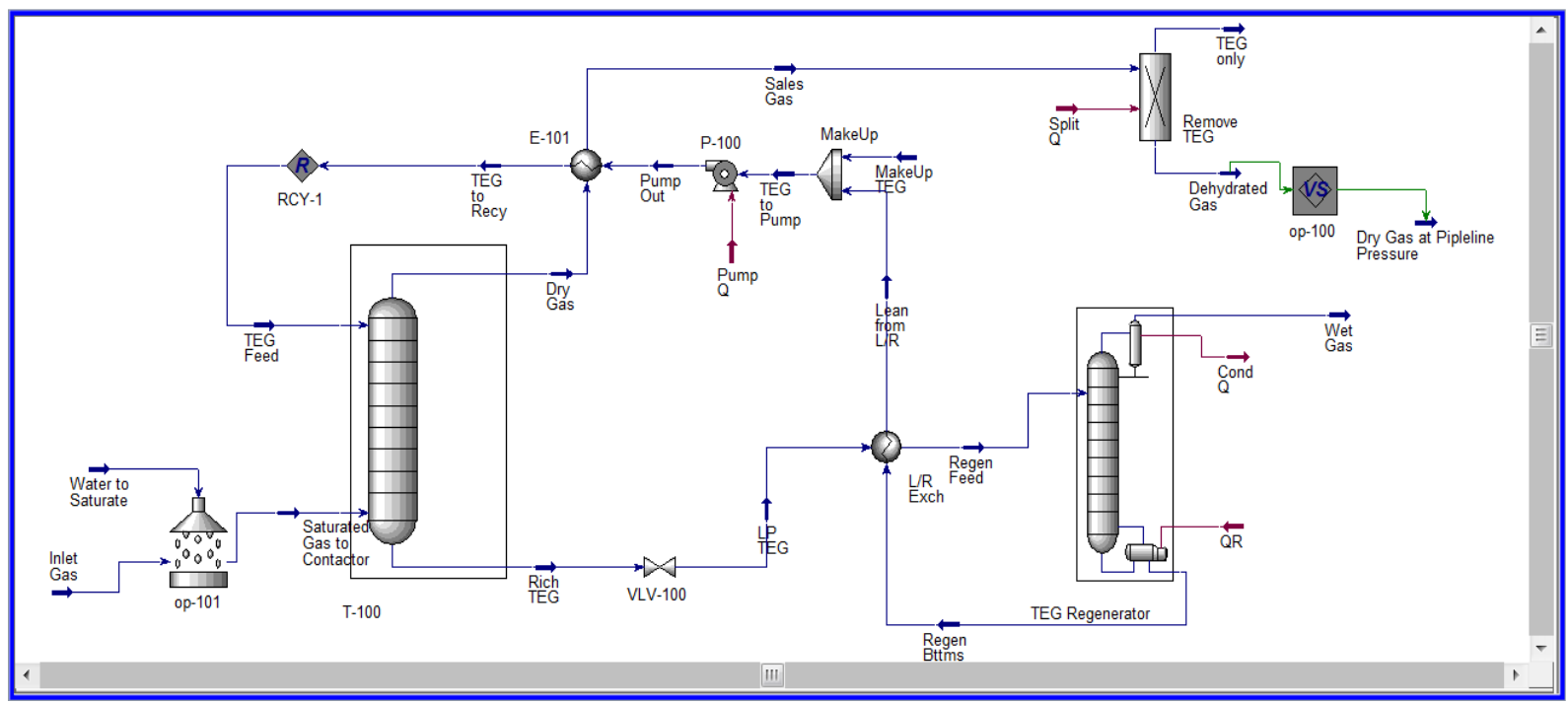

Fig.6. Process simulation diagram for TEG gas dehydration process

\section{ANALYZING RESULTS}

The standard industrial specifications limits are a dew point of $28^{\circ} \mathrm{F}\left(-2.23^{\circ} \mathrm{C}\right)$ and a water content of $7 \mathrm{lb} / \mathrm{MMscf}$. Thus they must be below these limitations. Virtual stream Aspen HYSYS tool used to investigate if the product dry gas satisfies the limits at plant pipeline pressure $(600$ psia). The dew point temperature and water content are determined, well below the limits Table (2). As an additional precautions finding the hydrates formation temperature using hydrate formation stream analysis tool applied on the produced dry gas to be $5.92^{\circ} \mathrm{F}\left(-14.49^{\circ} \mathrm{C}\right)$ and hydrates can't exist at dry gas stream temperature of $79.31^{\circ} \mathrm{F}\left(26.28^{\circ} \mathrm{C}\right)$. 
Table2. Resulted dehydrated gas specifications at pipeline conditions

\begin{tabular}{|l|c|c|} 
& Specifications limits & Sales Gas specifications \\
\hline Water Dew Point [Gas] & $28{ }^{\circ} \mathrm{F}$ & $9.618^{\circ} \mathrm{F}$ \\
\hline Water Content & $7 \mathrm{lb} / \mathrm{MMscf}$ & $1.282 \mathrm{lb} / \mathrm{MMscf}$ \\
\hline
\end{tabular}

\section{CONCLUSION}

The effective role of process simulation is to be close to the pragmatism of real process plant operation. So the leverage of thermodynamic alternatives techniques and relationships introduce further accuracy, validity and insight of chemical process behavior description. Application of CPA model as a surrogate to glycol package emphasis this concept resulted in a produced sales gas satisfies pipeline specifications standards through dehydration modeling using TEG solvent that most applied in such processes and achieving optimum operation conditions and process integration (material/energy) to optimize process economics.

\section{REFERENCES:}

[1] Aspentech,

NaturalGasDehydrationWithTEG. (C)

AspenTech. All Rights Reserved.

EA1031.31.05, 2003 Retrieved from

https://www.scribd.com/document/3878

3981/09-

NaturalGasDehydrationWithTEG.

[2] Christensen, D.L., Gas Dehydration Thermodynamic simulation of the water/glycol mixture. Esbjerg,

Denmark, February 2009 Retrieved from

https://projekter.aau.dk/projekter/files/1 7059482/Gas_Dehydration.pdf.

[3] Aspentech, Aspen HYSYS Property

Packages, Overview and Best Practices

for Optimum Simulations. Aspen

Process Engineering Webinar, October, 2006 Retrieved from

http://sites.poli.usp.br/d/pqi2408/BestPr acticesOptimumSimulationsHYSYSPro pertyPackages.pdf.

[4] Abdulrahman, R., I. Sebastine, and F. Hanna, Natural gas dehydration process simulation and optimization: a case study of Khurmala field in Iraqi Kurdistan region. International Journal of chemical, molecular nuclear, material and metallurgical engineering 6 (7)(2013) 350, 2014. 353 Retrieved from.

[5] Sayed, A.E.-R., I. Ashour, and M. Gadalla, Integrated process development for an optimum gas processing plant. Chemical Engineering Research and Design, 2017. 124: p. 114-123 Retrieved from.

[6] Aspentech, Dehydration Process Optimization. [Online], available:, 2015 Retrieved from https://www.aspentech.com/en/applicati ons/engineering/dehydration-processoptimization.

[7] Tsuji, T., T. Hiaki, and M. Hongo, Vapor- Liquid Equilibria of the Three Binary Systems: Water+ Tetraethylene Glygol (TEG), Ethanol+ TEG, and 2Propanol+ TEG. Industrial \& engineering chemistry research, 1998. 37(5): p. 1685-1691 Retrieved from. [8] Aspentech, Dehydration with Aspen HYSYS: Validation of the CPA Property Package. [Online] Available, 2018 Retrieved from https://www.aspentech.com/en/resource s/white-papers/dehydration-with-aspenhysys-validation-of-the-cpa-propertypackage. 


\section{CPA النمذجة والمحاكاة لتخفيف الغاز الطبيعى باستخدام}

ان الغرض من هذا البحث هو دراسة عملية التجفيف للغاز الطبيعي عن طريق الامتصاص باستخدام ثلاثي الإثبلين جليكول وتطوير النمذجة والمحاكاة لعملية تجفيف الغاز الطبيعى بواسطة برنامج أسبن هايسيس الاصدار 8.8 باستخدام معادلة الحاله التكعيبيه كما هو الحال في شركة جاسكو هناك حاجة إلى تجفيف الغاز الطبيعي لإزالة المياه المرتبطة بالغاز الطبيعي في شكل بخار ـ أدركت شركات نصنيع الغاز الطبيعي أن عمليى التجفيف ضروريه لضمان التتغيل السلس والامنل لخطوط نقل الغازالطبيعى وتفادى الكثير من المشكلات ؛ حيث ان عملية التجفيف تمنع تكوين هيدرات الغاز وتقلل من التآكل. اذا ما لم يتم تجفيف الغاز الطبيعى من الماء ، فقد يتكثف الماء السائل في خط الأنابيب ويتراكم عند نقطة منخفضة على طول الخط ويقلل من سعة التدفق. يوجد عدة طرق لتجفيف الغاز الطبيعى .الطرق الرئيسية لعمليه تجفيف الغاز الطبيعى هي التبريد المباشر ، التبريد غير المباشر ، الامتصاص ، الادمصاص ، تغلغل الغاز والتبريد. تركز هذه الدراسة على طريقة الامتصاص باستخدم ثلاثى ايثلين الجلايكول التي تستخدم لإزالة الماء عن الغاز الطبيعي في شركة جاسكو وكذلك التركيز على نتائج الفرق بين حزمة الجليكول ومعادلة الحالة التكعيبيه ومقارنة النتائج الناتجه عن عملية النمذجة والمحاكاه مع النتائج المعملية. ان أداة التحليل في برنامج أسبن هايسيس تعمل كبديل لدورالتجارب المعطلية فى الصناعة ـ كما ان لديها دور هام ونتط فى تحديد درجة حرارة التى يتم عندها تكوين الهيدرات وتتبه على تجنب الوصول إلى هذه الفئة من درجة الحرارةكما ان الدور الهام لوحدة تجفيف الغاز الطبيعى هو تقليل المحتوى المائي داخل الغاز الطبيعي والوصول إلى نقطة الندى للمياه حتى نستطيع الحصول على مواصفات خط الأنابيب المسموح بها في الصناعة والتي يصبح فيها الغاز الطبيعي فعالاً لأغر اض تجارية. 